\title{
Laparoscopic surgery for Crohn's disease: a meta-analysis of perioperative complications and long term outcomes compared with open surgery
}

\author{
Sunil V Patel ${ }^{1,2^{*}}$, Sanjay VB Patel ${ }^{1}$, Sreeram V Ramagopalan ${ }^{2,3,4}$ and Michael C Ott ${ }^{1}$
}

\begin{abstract}
Background: Previous meta-analyses have had conflicting conclusions regarding the differences between laparoscopic and open techniques in patients with Crohn's Disease. The objective of this meta-analysis was to compare outcomes in patients with Crohn's disease undergoing laparoscopic or open surgical resection.

Methods: A literature search of EMBASE, MEDLINE, The Cochrane Central Register of Controlled Trials and the US National Institute of Health's Clinical Trials Registry was completed. Randomized clinical trials and non-randomized comparative studies were included if laparoscopic and open surgical resections were compared. Primary outcomes assessed included perioperative complications, recurrence requiring surgery, small bowel obstruction and incisional hernia.

Results: 34 studies were included in the analysis, and represented 2,519 patients. Pooled analysis showed reduced perioperative complications in patients undergoing laparoscopic resection vs. open resection (Risk Ratio $0.71,95 \% \mathrm{Cl}$ $0.58-0.86, \mathrm{P}=0.001$ ). There was no evidence of a difference in the rate of surgical recurrence (Rate Ratio $0.78,95 \% \mathrm{Cl}$ $0.54-1.11, \mathrm{P}=0.17$ ) or small bowel obstruction (Rate Ratio $0.63,95 \% \mathrm{Cl} 0.28-1.45, \mathrm{P}=0.28$ ) between techniques. There was evidence of a decrease in incisional hernia following laparoscopic surgery (Rate Ratio $0.24,95 \% \mathrm{Cl} 0.07$ $0.82, P=0.02$.

Conclusions: This is the largest review in this topic. The results of this analysis are based primarily on non-randomized studies and thus have significant limitations in regards to selection bias, confounding, lack of blinding and potential publication bias. Although we found evidence of decreased perioperative complications and incisional hernia in the laparoscopic group, further randomized controlled trials, with adequate follow up, are needed before strong recommendations can be made.
\end{abstract}

Keywords: Laparoscopy, Crohn's disease, Perioperative complications, Surgical recurrence, Hernia, Small bowel obstruction

\section{Background}

Despite many advances in the medical management of Crohn's disease, there is still a significant risk of surgical resection during the lifetime of a patient. Over $80 \%$ of patients diagnosed with primary ileocolic Crohn's disease have a surgical resection within 10 years of their diagnosis [1]. In patients undergoing initial surgical resection,

\footnotetext{
* Correspondence: spatel2009@meds.uwo.ca

'Divisions of General Surgery, The University of Western Ontario London, Ontario, ON, Canada

${ }^{2}$ Department of Epidemiology, London School of Hygiene and Tropical Medicine, London, United Kingdom

Full list of author information is available at the end of the article
}

over one quarter will require subsequent surgical resections for recurrent disease within five years of the initial resection [1]. Bernell et al., found that the median age of the first surgical resection in Crohn's disease is in the third decade. Given the young age of the patient population and the recurrent nature of the disease process, this patient population seems ideally suited for a laparoscopic approach to resection.

A Cochrane Review [2] on this topic was recently published. It focused on randomized controlled trials only. This review included 120 patients from 2 trials, and found no significant differences in perioperative complications

\section{Ciomed Central}


or long-term outcomes. The pooled results were likely underpowered to detect a difference in the long term outcomes. For recurrences requiring reoperation, a sample size of over 2800 patients per group would be needed to detect the difference seen in this review (for a power of $80 \%$ and an $\alpha$ of 0.05 ).

Previous meta-analyses [3-6] have been completed comparing laparoscopic and open surgery for Crohn's disease. The focus of these analyses was primarily on perioperative factors such as operating time, length of stay, return to diet and time to bowel movement. There were conflicting conclusions on the effects of laparoscopic surgery on perioperative complications and in the rate of recurrence. Only one of the analyses assessed the effect of small bowel obstruction [3] and found a benefit to laparoscopic surgery.

Since the publication of the most recent meta-analysis, there have been 13 publications exploring both perioperative complications and long-term outcomes in patients undergoing laparoscopic resection of Crohn's disease. This new data may help to clarify the inconclusive findings of prior meta-analyses, and warrants an up to date analysis.

This study assesses the risk of perioperative complications and long-term outcomes in patients undergoing resection for Crohn's disease either by laparoscopic or open surgery.

\section{Methods}

This Meta-Analysis adheres to the MOOSE reporting guidelines [7].

\section{Eligibility criteria}

Both randomized clinical trials and non-randomized studies were included. The population of interest were patients undergoing bowel resection for Crohn's disease. The intervention was laparoscopic surgical resection (including hand assisted laparoscopic resection), compared with open surgical resection.

Primary outcomes included both perioperative complications and long-term outcomes. Perioperative complications were defined as complications occurring within 30 days of surgery including wound infection, urinary tract infections, respiratory complications, anastomotic leak, intra abdominal abscess, bowel obstruction or prolonged ileus and reoperation for any reason. Longterm outcomes included recurrence of Crohn's disease requiring surgical intervention, small bowel obstruction and incisional hernia.

Publications comparing laparoscopic to open colorectal surgery were also included if data for patients undergoing resection for Crohn's disease could be extracted separately. Studies were excluded if there was no open surgery control group for comparison. Only the most

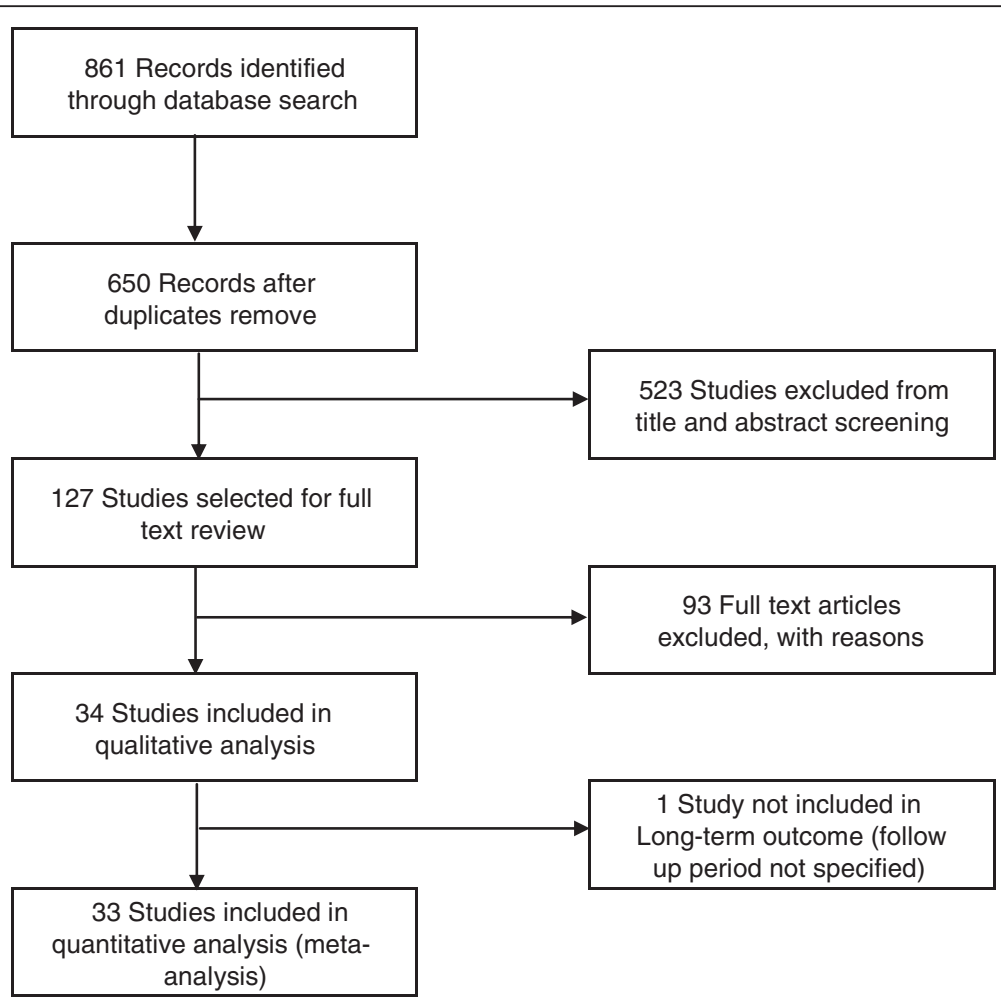

Figure 1 Flow Diagram of search results, and trial inclusion. 
Table 1 Summary of included studies: NR non-randomized, RCT randomized control trial, IC Ileocecal, PO perioperative complications, LT long term outcomes, a Median displayed

\begin{tabular}{|c|c|c|c|c|c|c|c|}
\hline Study & Patient No. & Methods & Participants & Intervention & Outcomes & $\begin{array}{l}\text { Long term follow } \\
\text { up (Mean, months) }\end{array}$ & Notes \\
\hline Alabaz et al. 2000 [10] & 74 & NR & CD patients & IC resection & $\mathrm{PO}, \mathrm{LT}$ & Study mean $=30$ & \\
\hline Allesandroni 2010 [11] & 200 & NR & CD patients & IC resection & $\mathrm{PO}, \mathrm{LT}$ & Lap $=52 ;$ Open $=60$ & \\
\hline Bemelman et al. 2000 [12] & 78 & NR & CD patients & IC resection & $\mathrm{PO}$ & & \\
\hline Benoist et al. 2003 [13] & 56 & NR & CD patients & IC resection & $\mathrm{PO}$ & & $\begin{array}{l}\text { Cases and controls } \\
\text { matched }\end{array}$ \\
\hline Bergamaschi et al. 2003 [14] & 92 & NR & CD patients & IC resection & $\mathrm{PO}, \mathrm{LT}$ & Lap $=60 ;$ Open $=60$ & \\
\hline Broquet et al. 2010 [15] & 62 & NR & CD patients & IC resection & $\mathrm{PO}$ & & $\begin{array}{l}\text { Patients with at least } 1 \\
\text { previous resection }\end{array}$ \\
\hline Courtney et al. 2011 [16] & 13 & NR & $\begin{array}{l}\text { Adolescent patients with } \\
\text { IBD }\end{array}$ & $\begin{array}{c}\text { Any bowel resection and } \\
\text { anastomosis }\end{array}$ & $\mathrm{PO}$ & & \\
\hline da Luz Moreira et al. 2007 [17] & 54 & NR & Crohn's colitis patients & $\begin{array}{l}\text { Colectomy for Crohn's } \\
\text { colitis }\end{array}$ & $\mathrm{PO}, \mathrm{LT}$ & $\operatorname{Lap}=12 ;$ Open $=40^{\mathrm{a}}$ & $\begin{array}{c}\text { Cases and controls } \\
\text { matched }\end{array}$ \\
\hline Diamond et al. 2001 [18] & 23 & NR & $\begin{array}{l}\text { Adolescent patients with } \\
\text { CD }\end{array}$ & IC resection & $\mathrm{PO}$ & & \\
\hline Duepree et al. 2002 [19] & 45 & NR & CD patients & IC resection & $\mathrm{PO}$ & & \\
\hline Dunker et al. 1998 [20] & 22 & NR & CD patients & IC resection & $\mathrm{PO}$ & & \\
\hline El Gazaaz et al. 2010 [21] & 456 & NR & $\begin{array}{l}\text { Patients undergoing } \\
\text { bowel anastomosis }\end{array}$ & $\begin{array}{c}\text { Any bowel resection and } \\
\text { anastomosis }\end{array}$ & Anastamotic leak rate & & $\begin{array}{l}\text { Cases and controls } \\
\text { matched }\end{array}$ \\
\hline Eshuis et al. 2008 [22] & 71 & NR & CD patients & IC resection & LT & $\operatorname{Lap}=104 ;$ Open $=103^{a}$ & $\begin{array}{l}\text { Long-term follow up to } \\
\text { study by Bemelman } 2000\end{array}$ \\
\hline Eshuis et al. 2010 [23] & 55 & RCT & CD patients & IC resection & LT & Lap $=78 ;$ Open $=82^{a}$ & $\begin{array}{l}\text { Follow up report on the } \\
\text { RCT completed by } \\
\text { Maartense et al. } 2006\end{array}$ \\
\hline Fichera et al. 2007 [24] & 146 & NR & CD patients & IC resection & $\mathrm{PO}, \mathrm{LT}$ & Lap $=26$, Open $=15$ & \\
\hline Huilgol et al. 2004 [25] & 40 & NR & CD patients & IC resection & $\mathrm{PO}$ & & \\
\hline Kishi et al. 2000 [26] & 35 & NR & $\begin{array}{l}\text { Stenotic lesions in CD } \\
\text { patients }\end{array}$ & IC resection & PO & & \\
\hline Lauro et al. 2004 [27] & 51 & NR & CD patients & $\begin{array}{c}\text { Any bowel resection and } \\
\text { anastomosis }\end{array}$ & $\mathrm{PO}$ & & \\
\hline Lowney et al. 2006 [28] & 113 & NR & CD patients & IC resection & $\mathrm{PO}, \mathrm{LT}$ & Lap = 60; Open = 81 & \\
\hline Luan et al. 2000 [29] & 40 & NR & CD patients & $\begin{array}{c}\text { Any bowel resection and } \\
\text { anastomosis }\end{array}$ & $\mathrm{PO}$ & & \\
\hline Maartense et al. 2006 [30] & 60 & RCT & CD patients & IC resection & $\mathrm{PO}$ & & \\
\hline Milsom et al. 2001 [31] & 60 & RCT & CD patients & IC resection & $\mathrm{PO}$ & & \\
\hline
\end{tabular}


Table 1 Summary of included studies: NR non-randomized, RCT randomized control trial, IC lleocecal, PO perioperative complications, LT long term outcomes,

\section{a Median displayed (Continued)}

\begin{tabular}{|c|c|c|c|c|c|c|c|}
\hline Msika et al. 2001 [32] & 46 & NR & CD patients & $\begin{array}{c}\text { Any bowel resection and } \\
\text { anastomosis }\end{array}$ & $\mathrm{PO}$ & & \\
\hline Nakajima et al. 2010 [33] & 38 & NR & Crohn's colitis & $\begin{array}{l}\text { Colectomy or subtotal } \\
\text { colectomy }\end{array}$ & $\mathrm{PO}$ & & $\begin{array}{l}\text { Hand assisted and } \\
\text { laparoscopic assisted } \\
\text { groups analyzed together }\end{array}$ \\
\hline Shore et al. 2003 [34] & 40 & NR & CD patients & IC resection & $\mathrm{PO}$ & & \\
\hline Sica et al. 2008 [35] & 28 & NR & CD patients & IC resection & $\mathrm{PO}$ & & \\
\hline Stocchi et al. 2008 [36] & 56 & $\mathrm{RCT}$ & CD patients & IC resection & LT & $\begin{array}{l}\text { Lap }=120 \\
\text { Open }=132\end{array}$ & $\begin{array}{l}\text { Follow up report on the } \\
\text { RCT completed by } \\
\text { Milsom et al. } 2001\end{array}$ \\
\hline Tabet et al. 2001 [37] & 61 & NR & CD patients & $\begin{array}{c}\text { Any bowel resection and } \\
\text { anastomosis }\end{array}$ & $\mathrm{PO}, \mathrm{LT}$ & $\begin{array}{l}\text { Lap }=39 \\
\text { Open }=42\end{array}$ & \\
\hline Tanaka et al. 2008 [38] & 48 & NR & CD patients & $\begin{array}{c}\text { Any bowel resection and } \\
\text { anastomosis }\end{array}$ & $\mathrm{PO}, \mathrm{LT}$ & Unknown & \\
\hline Thaler et al. 2005 [39] & 37 & NR & CD patients & IC resection & LT & & \\
\hline Uchikoshi et al. 2004 [40] & 43 & NR & Recurrent CD & $\begin{array}{c}\text { Bowel resection and } \\
\text { anastomosis }\end{array}$ & $\mathrm{PO}, \mathrm{LT}$ & $\begin{array}{l}\text { Lap }=29.6 \\
\text { Open }=71.9\end{array}$ & $\begin{array}{l}\text { Hand assisted and } \\
\text { laparoscopic assited } \\
\text { groups analyed together }\end{array}$ \\
\hline Umanskiy et al. 2010 [41] & 125 & NR & Crohn's colitis patients & $\begin{array}{c}\text { Colectomy for Crohn's } \\
\text { colitis }\end{array}$ & $\mathrm{PO}, \mathrm{LT}$ & $\begin{array}{l}\text { Lap }=20 \\
\text { Open }=29\end{array}$ & \\
\hline Von Allmen et al. 2003 [42] & 28 & NR & CD patients & $\begin{array}{c}\text { Any bowel resection and } \\
\text { anastomosis }\end{array}$ & $\mathrm{PO}$ & & \\
\hline Wu et al. 1997 [43] & 123 & NR & CD patients & IC resection & $\mathrm{PO}$ & & \\
\hline
\end{tabular}

NR Non-randomized, $R C T$ randomized control trial, IC lleocecal, $P O$ perioperative complications, $L T$ Long Term Outcomes, ${ }^{a}$ Median displayed. 
Table 2 Differences between laparoscopic and open surgery patients, ${ }^{a}$ Mean difference ${ }^{b}$ Risk ratio

\begin{tabular}{lccc}
\hline & No. studies & Mean difference or risk ratio (95\% Cl) & P Value \\
\hline Age, $y r$ & $24(n=2011)$ & $-1.41(-2.71 \text { to }-0.11)^{\mathrm{a}}$ & 0.03 \\
BMl, $\mathrm{kg} / \mathrm{m}^{2}$ & $14(n=1359)$ & $-0.65(-1.94 \text { to } 0.65)^{\mathrm{a}}$ & 0.32 \\
Length of disease, years & $14(n=974)$ & $-0.94(-3.02 \text { to } 1.15)^{\mathrm{a}}$ & 0.38 \\
Previous surgery & $16(n=1201)$ & $0.80(0.64 \text { to } 1.01)^{\mathrm{b}}$ & 0.06 \\
Preoperative steroids & $13(n=921)$ & $1.06(0.95 \text { to } 1.17)^{\mathrm{b}}$ & $-2.24(-2.50 \text { to }-1.98)^{\mathrm{a}}$ \\
Length of stay, days & $17(n=1005)$ & $-1.29(-1.59 \text { to }-0.98)^{\mathrm{a}}$ & $<0.001$ \\
Return to solid diet, days & $9(n=442)$ & $-0.80(-1.05 \text { to }-0.55)^{\mathrm{a}}$ & $<0.001$ \\
Time to flatus, days & $8(n=465)$ & $-0.68(-0.94 \text { to }-0.43)^{\mathrm{a}}$ & $<0.001$ \\
Time to bowel movement, days & $6(n=378)$ & & $<0.001$ \\
\hline
\end{tabular}

recent publication data was included for analysis if there was duplication of patient data across multiple studies.

\section{Information sources and search}

The search was completed by two of the authors (SVP, SVBP), with input for search strategy from the institutions librarian. A search was completed in December, 2011 using EMBASE (1980 - 2011), MEDLINE (1948 2011), The Cochrane Central Register of Controlled Trials and the US National Institute of Health's Clinical Trials Registry. Bibliographies of related studies were searched. Search terms included "Crohn's Disease", "inflammatory bowel disease", "Laparoscopy" and "laparoscopic surgery". Terms were combined with Boolean expressions to limit the search. The study was not limited to English language journals. Non-english language articles were translated into English.

Two independent reviewers assessed titles and abstracts for relevant articles. Full text review was performed on identified studies. Both reviewers assessed each study, to determine if it met the inclusion criteria. The kappa statistic was used to assess inter-rater agreement.

Data was extracted by two independent reviewers using standardized forms. Study details, patient characteristics, follow up periods and outcomes were extracted.

\section{Risk of bias assessment}

Study quality was assessed using two methods. Nonrandomized comparative trials were assessed using the
Newcastle - Ottawa quality assessment scale, [8] as recommended in the Cochrane Handbook [9]. This scale assigns a star rating based on pre-specified criteria. A maximum of one star can be attained for each category, except comparability which has a maximum of 2 stars. The more stars a study obtains, the higher the quality. Randomized controlled trials were assessed as discussed in the Cochrane Handbook [9].

\section{Statistical analysis}

Data was analyzed using STATA 12 (StataCorp LP, College Station Texas, 2011). For short- term complications, risk ratios and 95\% confidence intervals were calculated. Rate ratios and 95\% confidence intervals, using patient years, were calculated for long-term outcomes. Using rates instead of risk allows for comparison between groups with unequal follow up duration.

The fixed effect model using the inverse variance method was used for these calculations. Risk difference and 95\% confidence intervals were calculated for continuous variables, using the fixed effect model with the inverse variance method. A fixed effect model was selected because of the large number of trials and large variation in study size. This allows for larger trials to be weighted more strongly in the pooled estimate. $\mathrm{I}^{2}$ values were used to determine heterogeneity between studies.

Publication bias was assessed using funnel plots. Statistical test for funnel plot asymmetry was completed as recommended in the Cochrane Handbook.

Table 3 Risk of bias of randomized controlled trials

\begin{tabular}{|c|c|c|c|c|c|c|c|}
\hline Study & Randomization & $\begin{array}{c}\text { Allocation } \\
\text { concealment }\end{array}$ & Blinding & $\begin{array}{l}\text { Incomplete } \\
\text { outcome data }\end{array}$ & $\begin{array}{l}\text { Selective } \\
\text { reporting }\end{array}$ & $\begin{array}{l}\text { Other potential } \\
\text { sources of bias }\end{array}$ & $\begin{array}{c}\text { Risk of } \\
\text { bias }\end{array}$ \\
\hline $\begin{array}{l}\text { Milsom } 2001 \\
\text { [31] }\end{array}$ & $\begin{array}{l}\text { Unclear method } \\
\text { of randomization }\end{array}$ & $\begin{array}{l}\text { Unclear: not } \\
\text { discussed }\end{array}$ & $\begin{array}{l}\text { High risk: unable to } \\
\text { blind due to type of } \\
\text { intervention }\end{array}$ & Low risk & Low risk & $\begin{array}{c}\text { Unclear risk: not intention } \\
\text { to treat analysis. Patients } \\
\text { randomized after } \\
\text { laparoscopy }\end{array}$ & High \\
\hline $\begin{array}{l}\text { Maartense } 2006 \\
\text { [30] }\end{array}$ & $\begin{array}{l}\text { Unclear method } \\
\text { of randomization }\end{array}$ & $\begin{array}{c}\text { Low risk: sealed } \\
\text { envelopes }\end{array}$ & $\begin{array}{l}\text { High risk: unable to } \\
\text { blind due to type of } \\
\text { intervention }\end{array}$ & Low risk & Low risk & None & High \\
\hline
\end{tabular}


Table 4 Quality assessment of non-randomized controlled trials

\begin{tabular}{|c|c|c|c|c|c|c|c|c|}
\hline \multirow[b]{2}{*}{ Study } & \multicolumn{4}{|c|}{ Selection } & \multirow[b]{2}{*}{$\begin{array}{l}\text { Comparability } \\
\text { of cohorts }\end{array}$} & \multicolumn{3}{|c|}{ Outcome } \\
\hline & $\begin{array}{l}\text { Representativeness } \\
\text { of the exposed } \\
\text { cohort }\end{array}$ & $\begin{array}{l}\text { Selection of } \\
\text { the non } \\
\text { exposed cohort }\end{array}$ & $\begin{array}{l}\text { Ascertainment } \\
\text { of exposure }\end{array}$ & $\begin{array}{l}\text { Outcome(s) } \\
\text { absent at } \\
\text { start of study }\end{array}$ & & $\begin{array}{l}\text { Assessment } \\
\text { of outcome }\end{array}$ & $\begin{array}{l}\text { Adequate } \\
\text { follow up } \\
\text { time }\end{array}$ & $\begin{array}{l}\text { Adequacy of } \\
\text { follow up }\end{array}$ \\
\hline $\begin{array}{l}\text { Alabaz } 2000 \\
{[10]}\end{array}$ & $*$ & $*$ & $*$ & $*$ & & $*$ & * & $*$ \\
\hline $\begin{array}{l}\text { Allesandroni } \\
2010 \text { [11] }\end{array}$ & * & & * & * & * & * & * & * \\
\hline $\begin{array}{l}\text { Bemelman } \\
2000 \text { [12] }\end{array}$ & * & & * & * & * & $*$ & $*$ & $*$ \\
\hline $\begin{array}{l}\text { Benoist } 2003 \\
{[13]}\end{array}$ & * & & * & * & $* *$ & * & * & * \\
\hline $\begin{array}{l}\text { Bergamaschi } \\
2003[14]\end{array}$ & * & & $*$ & $*$ & $*$ & $*$ & $*$ & $*$ \\
\hline $\begin{array}{l}\text { Broquet } 2010 \\
\text { [15] }\end{array}$ & * & $*$ & $*$ & * & * & * & $*$ & * \\
\hline $\begin{array}{l}\text { Courtney } 2011 \\
\text { [16] }\end{array}$ & * & & * & * & & * & * & $*$ \\
\hline $\begin{array}{l}\text { da Luz Moreira } \\
2007 \text { [17] }\end{array}$ & * & * & * & * & $* *$ & * & & * \\
\hline $\begin{array}{l}\text { Diamond } 2001 \\
\text { [18] }\end{array}$ & $*$ & $*$ & * & $*$ & * & $*$ & $*$ & $*$ \\
\hline $\begin{array}{l}\text { Duepree } 2002 \\
\text { [19] }\end{array}$ & $*$ & $*$ & $*$ & * & & * & $*$ & * \\
\hline $\begin{array}{l}\text { Dunker } 1998 \\
\text { [20] }\end{array}$ & & * & $*$ & $*$ & & $*$ & * & $*$ \\
\hline $\begin{array}{l}\text { El Gazaaz } 2010 \\
\text { [21] }\end{array}$ & $*$ & $*$ & $*$ & $*$ & $* *$ & $*$ & $*$ & * \\
\hline $\begin{array}{l}\text { Eshuis } 2008 \\
\text { [22] }\end{array}$ & $*$ & $*$ & $*$ & $*$ & * & $*$ & $*$ & $*$ \\
\hline $\begin{array}{l}\text { Fichera } 2007 \\
\text { [24] }\end{array}$ & $*$ & * & $*$ & * & & * & & * \\
\hline $\begin{array}{l}\text { Huilgol } 2004 \\
{[25]}\end{array}$ & * & & * & * & & * & * & * \\
\hline Kishi 2000 [26] & $*$ & $*$ & $*$ & $*$ & & $*$ & * & * \\
\hline $\begin{array}{l}\text { Lauro } 2004 \\
\text { [27] }\end{array}$ & $*$ & $*$ & * & * & $*$ & * & * & * \\
\hline $\begin{array}{l}\text { Lowney } 2006 \\
\text { [28] }\end{array}$ & & & $*$ & * & * & * & * & * \\
\hline Luan 2000 [29] & & & $*$ & * & & * & * & * \\
\hline $\begin{array}{l}\text { Msika } 2001 \\
\text { [32] }\end{array}$ & $*$ & $*$ & * & * & * & * & * & * \\
\hline $\begin{array}{l}\text { Nakajima } 2010 \\
\text { [33] }\end{array}$ & $*$ & $*$ & * & * & & * & * & * \\
\hline $\begin{array}{l}\text { Shore } 2003 \\
\text { [34] }\end{array}$ & & $*$ & $*$ & * & * & $*$ & $*$ & $*$ \\
\hline Sica 2008 [35] & $*$ & $*$ & $*$ & $*$ & $*$ & $*$ & $*$ & * \\
\hline $\begin{array}{l}\text { Tabet } 2001 \\
\text { [37] }\end{array}$ & * & * & * & * & * & * & * & * \\
\hline $\begin{array}{l}\text { Tanaka } 2008 \\
\text { [38] }\end{array}$ & * & * & * & * & $*$ & * & & * \\
\hline $\begin{array}{l}\text { Thaler } 2005 \\
\text { [39] }\end{array}$ & & * & * & * & * & * & $*$ & $*$ \\
\hline
\end{tabular}


Table 4 Quality assessment of non-randomized controlled trials (Continued)

\begin{tabular}{|c|c|c|c|c|c|c|c|c|}
\hline $\begin{array}{l}\text { Uchikoshi } \\
2004 \text { [40] }\end{array}$ & & & * & * & * & * & * & * \\
\hline $\begin{array}{l}\text { Umanskiy } \\
2010 \text { [41] }\end{array}$ & * & * & * & * & * & * & & * \\
\hline $\begin{array}{l}\text { Von Allmen } \\
2003 \text { [42] }\end{array}$ & $*$ & * & * & * & * & * & $*$ & * \\
\hline Wu 1997 [43] & * & * & * & * & & * & * & * \\
\hline
\end{tabular}

A study can be awarded a maximum of 1 star $\left(^{*}\right)$ in each of the selection and outcome categories, and a maximum of 2 stars $(* *)$ in the comparability section.

\section{Additional analysis}

A priori subgroup analysis was planned to assess differences in perioperative complications between randomized controlled trials and non-randomized comparative trials. Subgroup analysis was also planned to determine if the type of resection affected the long term outcomes. The test of interaction was used to assess heterogeneity between subgroups.

Sensitivity analysis was completed for rates of long-term outcomes. For our analysis, rate ratios were calculated using studies with known follow up duration in both groups. A sensitivity analysis was completed, including studies with incomplete follow up data, to assess the effect these studies had on the rate ratio. In this analysis, it was assumed that follow up duration was the same between groups and equal to the duration given for the entire study population. The test of interaction was used to assess the heterogeneity between these rate ratios.

\section{Results}

A literature search found 861 articles. After eliminating duplicates and identifying relevant studies, 127 articles

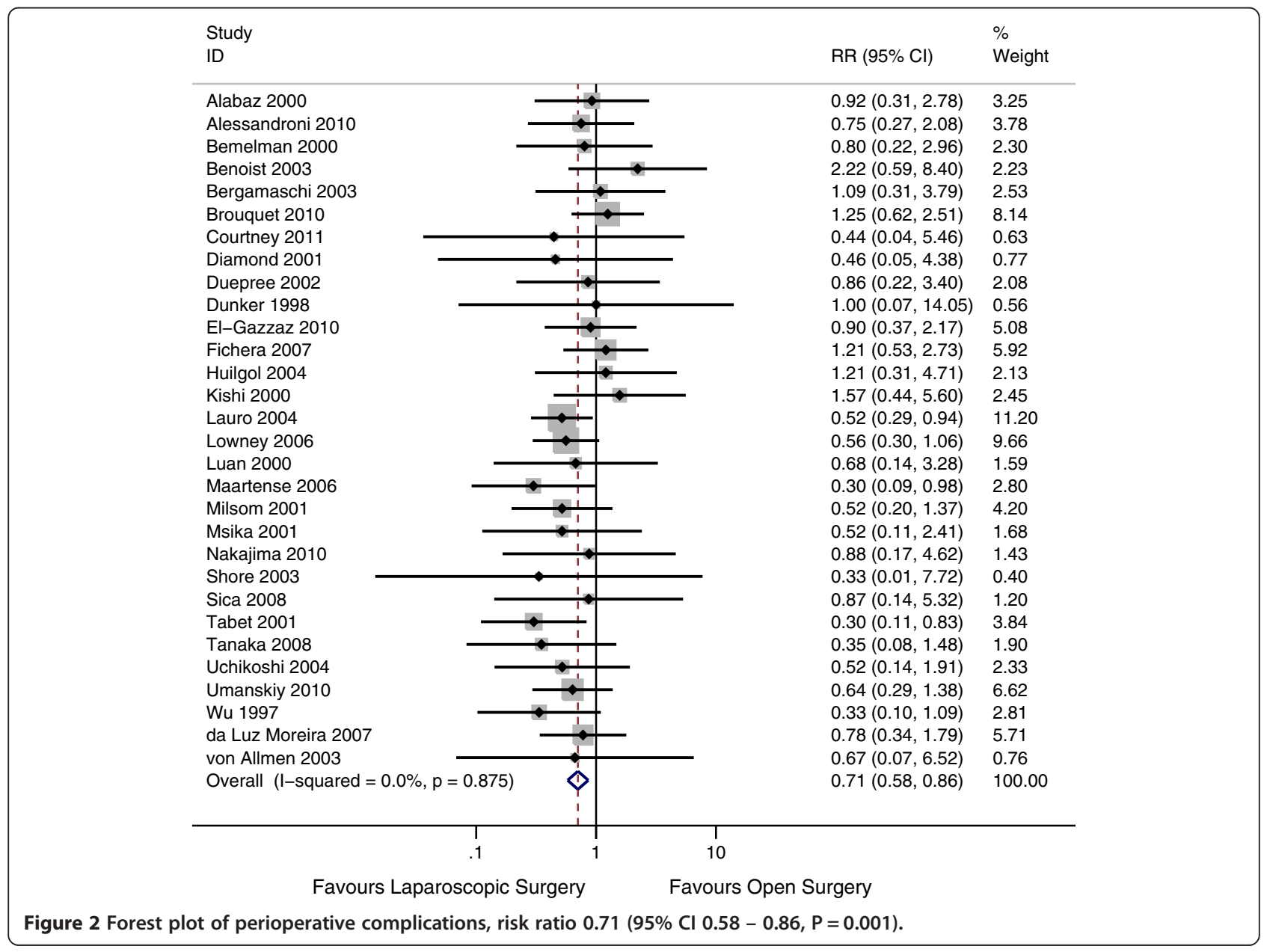




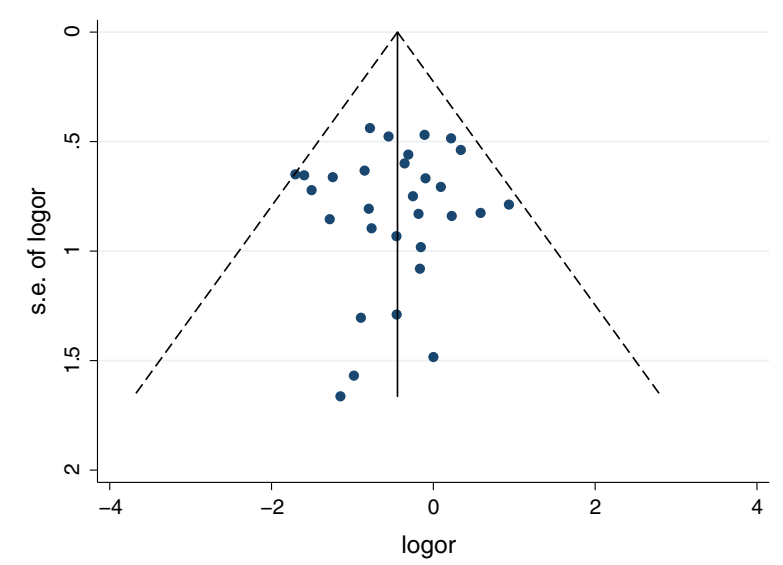

Figure 3 Funnel plot from perioperative complications. Test for assymetry, $P=0.75$.

were selected for full text review. Of these, 34 articles were included in the study (Figure 1). A total of 2,519 patients were included in our analysis. Two independent reviewers assessed articles for inclusion. The weighted kappa statistic was 0.92, which indicated very good agreement between the two reviewers. Disagreements were resolved through discussion and consensus.

A summary of included articles can be found in Table 1. Included studies were published from 1997 - 2011, and included both randomized controlled trials and nonrandomized studies. The number of patients in these studies ranged from 13 - 456. Weighted Mean Differences in age, BMI, length of disease, length of stay, and time to diet, flatus and bowel movement can be found in Table 2 . Risk ratio of preoperative steroid use and previous surgery can also be found in Table 2. Laparoscopic patients were younger $(P=0.03)$, while other characteristics were similar between groups. Shorter length of stay, earlier return to solid diet, time to flatus and time to bowel movement were seen in the laparoscopic group.

There were four articles which included data from two randomized controlled trials $[23,30,31,36]$. The studies by
Eshius [23] and Stocchi [36] included long-term outcomes from the initial studies by Maartense [30] and Milsom [31], respectively. The risk of bias of these studies can be found in Table 3. In both cases the risk of bias was deemed to be high. Neither study had adequate blinding of study personnel or patients. As well, in the study by Milsom et al., the decision for randomization did not occur until after a diagnostic laparoscopy was completed and the patient deemed appropriate for laparoscopic resection.

The quality assessment of the non-randomized trials can be found in Table 4. Thirty observational trials [10-22, 24-29,32-35,37-43] were included in this analysis. Twenty four of the 30 trials (80\%) used consecutive patients over a specified time period in selecting laparoscopic patients. These are likely representative of Crohn's patients requiring surgical intervention. The other six studies did not use consecutive patients, and did not describe how the included laparoscopic patients were selected. Twenty one of the studies $(70 \%)$ selected open surgical patients from the same population as the laparoscopic patients. The other 9 studies selected the open surgical patients from historic periods. The laparoscopic and open groups were comparable for at least age and gender in 20 studies (67\%). Three of the studies matched the open group to the laparoscopic group on several different factors, including age, gender, body mass index, disease severity or steroid use. Adequate follow up duration was seen in all studies looking at short term outcomes. Of the 12 observation studies looking at long term outcomes [10,11,14,17,22,24,28,37-41], 3 studies $[17,24,41]$ had less than 2 years of follow up in one of the groups, while one [38] did not specify the follow up duration at all.

Two studies $[33,40]$ included patients undergoing both hand assisted laparoscopic surgery and laparoscopic assisted surgery. These two groups were analyzed together in the laparoscopic surgery group. All other studies compared laparoscopic surgery to open surgery.

The majority of studies looked at patients undergoing ileocecal resection only. Nine studies [16,21,27,29,32, $37,38,40,42]$ included patients with any bowel resection.

Table 5 Pooled risk ratios of complications in Crohn's patients undergoing resection by laparoscopic or open technique

\begin{tabular}{|c|c|c|c|c|c|c|c|c|}
\hline Perioperative complication & $\begin{array}{l}\text { Number of } \\
\text { studies }\end{array}$ & $\begin{array}{c}\text { Total number of } \\
\text { patients }\end{array}$ & Laparoscopic & $\begin{array}{c}\text { Open } \\
\text { surgery }\end{array}$ & Risk ratio & $\begin{array}{l}\text { 95\% Confidence } \\
\text { interval }\end{array}$ & P Value & 12 \\
\hline All & 30 & 2300 & $12.00 \%$ & $17.90 \%$ & 0.71 & $0.58-0.86$ & 0.001 & $0 \%$ \\
\hline Wound infection & 25 & 1670 & $5.80 \%$ & $6.10 \%$ & 0.86 & $0.60-1.25$ & 0.43 & $0 \%$ \\
\hline Prolonged lleus/ bowel obstruction & 14 & 1012 & $3.90 \%$ & $4.70 \%$ & 0.83 & $0.48-1.42$ & 0.49 & $0 \%$ \\
\hline Respiratory complication & 11 & 825 & $0.80 \%$ & $2.50 \%$ & 0.57 & $0.25-1.33$ & 0.19 & $0 \%$ \\
\hline Urinary tract infection & 5 & 367 & $1.90 \%$ & $3.30 \%$ & 0.65 & $0.21-2.02$ & 0.46 & $0 \%$ \\
\hline Anastamotic leak & 12 & 1261 & $2.70 \%$ & $2.70 \%$ & 1 & $0.55-1.82$ & 1 & $0 \%$ \\
\hline Intraabdominal abscess & 15 & 1121 & $2.70 \%$ & $4.40 \%$ & 0.69 & $0.39-1.20$ & 0.19 & $0 \%$ \\
\hline$<30$ day reoperation & 13 & 917 & $2.40 \%$ & $4.00 \%$ & 0.72 & $0.37-1.38$ & 0.32 & $0 \%$ \\
\hline
\end{tabular}




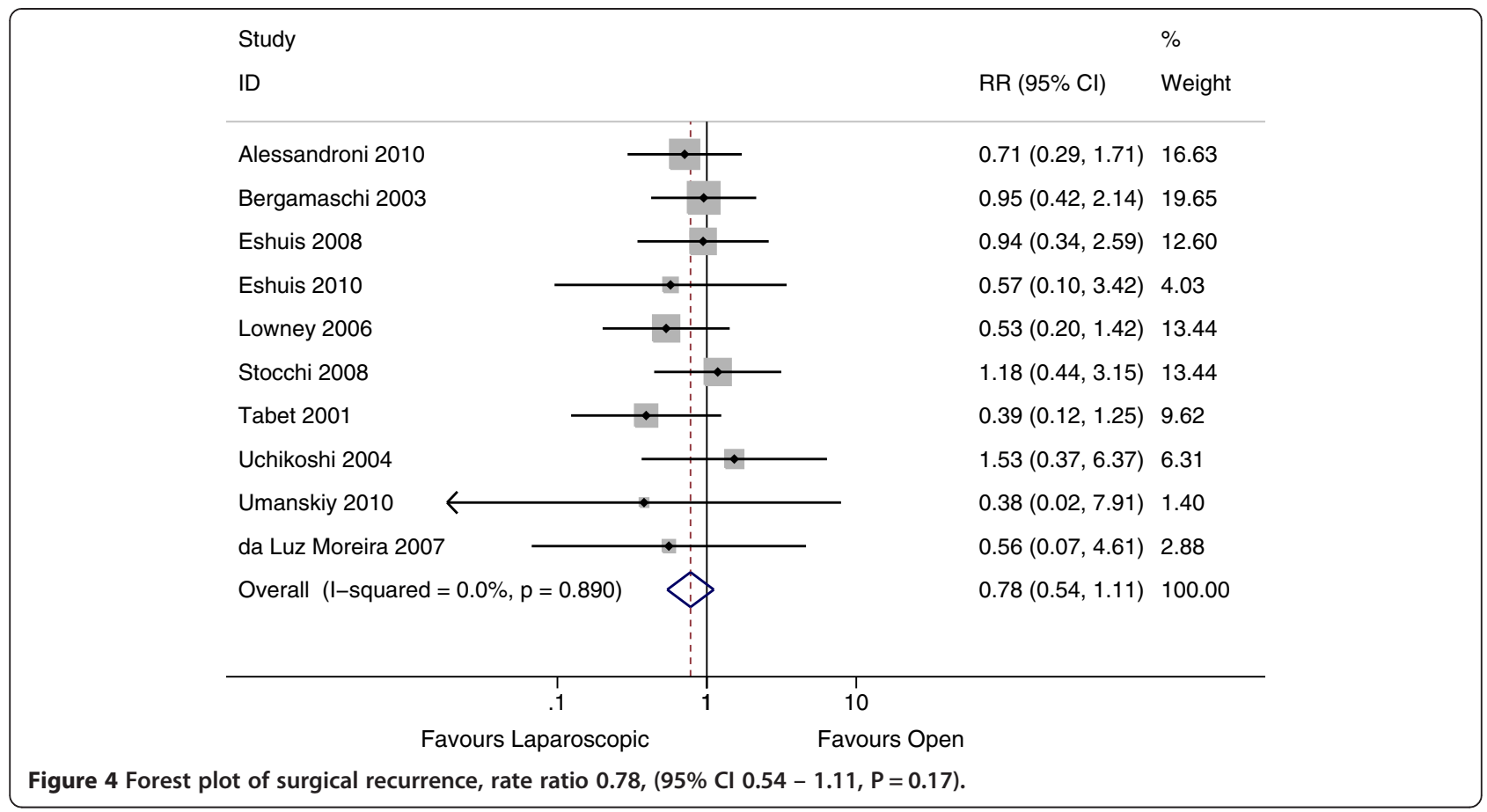

These resections included ileocecal resection, other small bowel resections, segmental colectomy and subtotal colectomy. Three studies $[17,33,41](20,32,39)$ looked exclusively at patients undergoing colectomy for Crohn's colitis.

The study by El-Gazaaz et al. [21] looked at patients undergoing bowel resection and anastomosis. These included colorectal cancer patients, Crohn's disease patients and patients with diverticular disease. The primary outcome in this study was anastomotic leak rate and
Crohn's disease patients were analyzed independently, and matched to an open surgery control group. One study [16] included both Crohn's disease and ulcerative colitis patients, and included data for the subset of Crohn's disease patients. All other studies looked exclusively at Crohn's disease patients.

\section{Perioperative complications}

Thirty studies [10-21,24-35,37,38,40-43] addressed the perioperative complication risk in the two groups. This

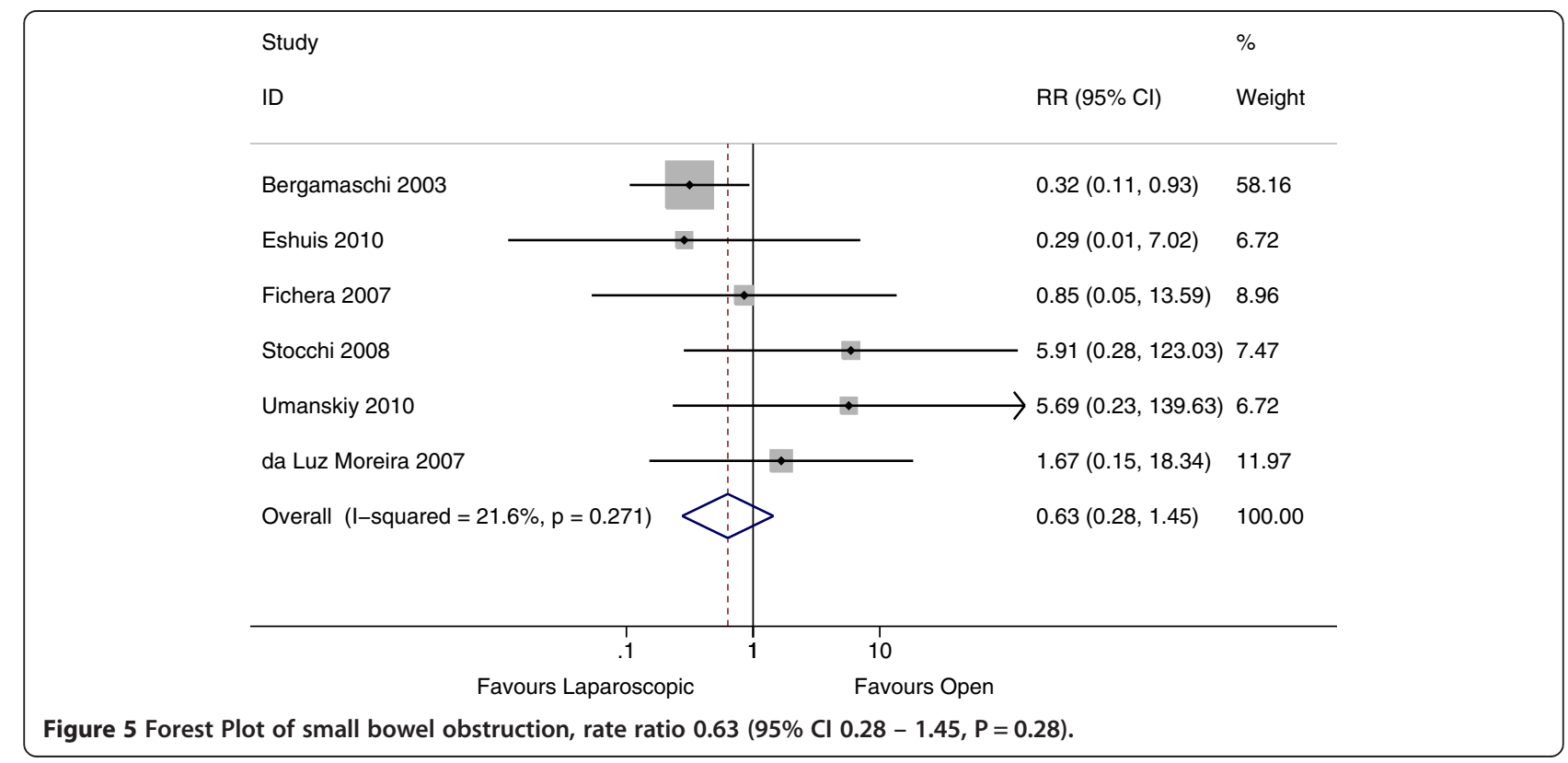


included 1079 laparoscopic patients and 1221 open surgery patients. The perioperative complication risk in the laparoscopic group was $12 \%$ compared with $18 \%$ in the open group. There is very strong evidence of a reduced risk of perioperative complications in the laparoscopic group (Risk Ratio 0.71, 95\% CI $0.58-0.86, \mathrm{P}=0.001$ ). There was statistical homogeneity in this outcome, with an $\mathrm{I}^{2}$ of $0 \%(\mathrm{P}=0.87)$ (Figure 2). Publication bias was assessed by funnel plot (Figure 3) There was no evidence of assymetry seen in the funnel plot $(P=0.75)$.

A subgroup analysis was completed evaluating the two randomized controlled trials. This subgroup showed a significant decrease in perioperative complications in laparoscopic surgery patients compared with open surgery patients (Risk Ratio $0.42 ; 95 \%$ CI $0.20-0.88 ; \mathrm{p}=$ 0.02 ). The test of interaction between this subgroup and the non-randomized trials showed no evidence of a subgroup effect $(p=0.16)$, indicating that the findings between the randomized controlled trials and nonrandomized trials were compatible.

All assessed complications were consistent with a reduction in the laparoscopic group. Due to the lack of power, none of these measures reached significance. We found no evidence of a difference in risk of intraabdominal abscess $(P=0.19)$, risk of prolonged ileus or perioperative bowel obstruction $(\mathrm{P}=0.49)$, risk of wound infection $(\mathrm{P}=$ $0.43)$, risk of anastomotic leak rate $(\mathrm{P}=1.00)$, risk of 30 day re-operation rate $(\mathrm{P}=0.32)$, risk of urinary tract infection $(\mathrm{P}=0.46)$ or risk of respiratory complications $(\mathrm{P}=$ 0.19) (Table 5).

\section{Long -term outcomes}

Long-term outcomes included surgical recurrence, small bowel obstruction and incisional hernia. A total of 14 studies $[10,11,14,17,22-24,28,36-41]$ assessed at least one of these outcomes. The duration of follow up was variable between studies and ranged from 12 to 132 months.

To negate the variability in the follow up period between groups, rates of long term outcomes were assessed based on person years of follow up. Follow up duration by intervention was included in 11 studies, and incomplete in 3 studies. The study by Tanaka et al. [38] did not specifically address the duration of the follow up period and was excluded from further analysis. The studies by Alabaz et al. [10] and Thaler et al. [39] did not specify follow up duration by individual group, but instead gave the average follow up of all patients.

Surgical recurrence was discussed in 12 studies, 10 of which included follow up duration by group. These 10 studies represented a total of 4,323 person years. Only two of the studies $[22,28]$ discussed the use of chemoprophylaxis post operatively to prevent recurrence. Neither study found a difference in rates of chemoprophylaxis between groups.

The rate of surgical recurrence in the laparoscopic group was 25 per 1000 person years compared with 34 per 1000 person years in the open group. This difference was not significant (Rate Ratio 0.78, 95\% CI $0.54-1.11$, $\mathrm{P}=0.17, \mathrm{I}^{2}=0 \%$ ) (Figure 4). There was no evidence of publication bias from the funnel plot $(\mathrm{P}=0.65)$.

Including the studies by Alabaz et al. and Thaler et al., showed a similar rate ratio with no significant difference between these estimates $(P=1.00)$. Subgroup analysis by type of resection was performed. There was no evidence of a difference in recurrence rates between patients undergoing ileocolic resection, colectomy or other resection $(\mathrm{P}=0.45)$.

Small bowel obstruction was assessed in 7 studies, 6 of which included follow up duration by group. These 6

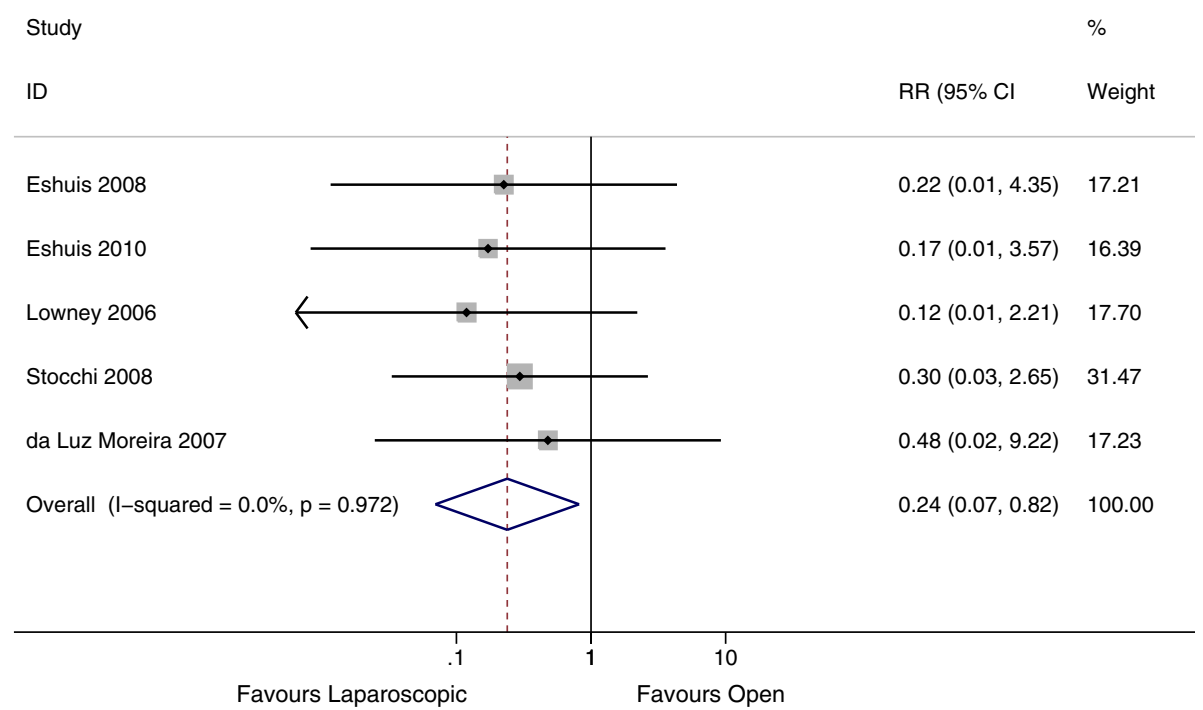

Figure 6 Forest plot of incisional hernia, rate ratio $0.24(95 \% \mathrm{Cl} 0.07-0.82, \mathrm{P}=0.02)$. 
studies represented a total of 1991 person years. The rate of small bowel obstruction was 10 per 1000 person years in the laparoscopic group compared with 19 per 1000 person years in the open group. There was no evidence of a difference between groups (Rate Ratio 0.63, $95 \%$ CI $0.28-1.45, \mathrm{P}=0.28, \mathrm{I}^{2}=26 \%$ ) (Figure 5). No publication bias was appreciated from the funnel plot $(\mathrm{P}=0.15)$. Including the study by Alabaz et al. in this analysis showed a similar rate ratio $(\mathrm{P}=0.69)$.

Incisional hernia was evaluated in 6 studies, 5 of which included follow up by group. There were a total of 2329 person years in these 5 studies. The rate of incisional hernia in the laparoscopic group was 1 per 1000 person years, compared with 12 per 1000 person years in the open group (Rate Ratio 0.24, 95\% CI $0.07-0.82$, P = 0.02, $\mathrm{I}^{2}=0 \%$ ) (Figure 6). Including the study by Thaler et al. in the analysis, showed a similar effect estimate, with no difference between estimates $(\mathrm{P}=0.91)$.

\section{Discussion}

An updated meta-analysis of laparoscopic surgery in Crohn's disease was performed. This analysis includes more than double the number of trials of previous metaanalyses and to our knowledge represents the largest and most complete collection of published data on this topic.

Previous meta-analyses have had conflicting results regarding the benefits of laparoscopic surgery in reducing perioperative complications. The studies by Dasari et al. [2], Polle et al. [6] and Tilney et al. [5] found no evidence of a difference in perioperative complications while Rosman et al. [3] and Tan et al. [4] did find a significant difference. Through the inclusion of an additional 13 studies and over 1300 patients compared with the previous meta-analyses, we were able to show evidence of a decrease in total perioperative complications in the laparoscopic group. In all assessed complications, the Risk Ratio favoured laparoscopic surgery, but due to the imprecision in the estimate, this effect did not reach statistical significance. The lack of imprecision is related to the pooled estimate being underpowered to detect a difference in individual complications. Due to the infrequency of complications ( $\sim 5 \%$ per individual complication) seen in the open group, a study size of close to 14,000 subjects would be required to detect a $20 \%$ reduction in complication risk, with $80 \%$ power and $5 \%$ significance.

Whilst the majority of the trials were observational and have their clear limitations as discussed below, a subgroup analysis of RCTs also provided evidence of benefit of laproscopic surgery. The summary effect estimate of the RCTs was greater than that of all studies combined further highlighting the imprecision of the currently available data.

We found no evidence of a difference in rates of surgical recurrence or rates of small bowel obstruction, after pooled analysis. A previous meta-analysis [3] found a significant reduction in surgical recurrence with laparoscopic surgery (OR $0.51,95 \%$ CI $0.27-0.80$ ). This analysis included 6 studies. [10,14,32,34,36,37] Our study included an additional 7 studies $[11,17,22,23,28,40,41]$ and excluded 2 of the trials used in the previous metaanalysis because [32,34] neither of these two trials described surgical recurrence as an outcome. The prior result was limited by not accounting for the difference in follow up period between groups. Our results were based on rates, which allowed us to compare surgical recurrence between laparoscopic and open groups directly, and more accurately than the previous review.

\section{Strengths and limitations}

The strengths of this review include the thorough search of eligible studies, using explicit eligibility criteria, and the assessment of study quality. The breadth of this search allowed inclusion of over 30 studies and 2,510 patients, which corresponds to the largest, most comprehensive meta-analysis in this subject to date. We were also able to compare our results to those reported in previous meta-analyses.

Limitations of this analysis include the large number of non-randomized studies and limited number of randomized controlled trials. Unfortunately, only 2 randomized controlled trials exist, and included only 120 patients in total. These RCTs were also of poor quality with high risk of bias.

Although many of the included observational studies had similar baseline characteristics in the two groups, we did see a younger age in the laparoscopic group. In addition, these observation studies likely suffered from selection bias. Choosing healthier patients, with lower BMI and less comorbidities was likely more frequent in the laparoscopic group. These types of patients would be less likely to suffer post operative complications and incisional hernias.

Additionally, confounders (both known and unknown) are likely to exist within these observation studies. None of the included studies attempted to adjust for known confounders (such as immune suppression, age, comorbidities, $\mathrm{BMI})$. Adjusting for these variable may have resulted in a different pooled result. The use of chemoprophylaxis for preventing recurrence was discussed in only two of the 12 trials evaluating surgical recurrence, and differences may have an impacted our findings on recurrence.

A third limitation of the included observational studies, is the likely bias of the authors. In many cases, the authors were advocates of the laparoscopic technique and were more experienced in this technique than the majority of surgeons treating this condition. This may skew their results towards favouring laparoscopic techniques. Non-experts may not have the same results as in the publications. 
There was also no attempt at blinding patients in the included study. With the adoption of laparoscopic surgery as state of the art, there is a strong possibility of placebo effect.

\section{Conclusions}

Based primarily on non-randomized trials, laparoscopic surgery appears to reduce the risk of perioperative complications and the rate of incisional hernia in patients with Crohn's disease. There was no significant difference in long term outcomes between laparoscopic and open surgery, in terms of surgical recurrence or small bowel obstruction.

There is clearly a continued interest in assessing and reporting experience with laparoscopic surgery in Crohn's disease. We have shown that most of the evidence of outcomes surrounding this technique is based on non-randomized studies, which suffer from selection bias, detection bias, confounding and a lack of blinding. Laparoscopic technique has been widely adopted despite the lack of evidence. As such, we would recommend that any further studies in this area address current limitations and be appropriately powered randomized controlled trials, with adequate follow up duration.

\section{Competing interests}

The author's declare no competing interests in the publication of this manuscript.

\section{Authors' contributions}

SVP, MCO designed the study. SVP, SVBP completed the search and data extraction. SVP, SVBP, MCO, SVR completed the introduction, analysis and discussion

\section{Funding}

This study was partially funded through the Wellcome Trust [075491/Z/04].

\section{Author details}

'Divisions of General Surgery, The University of Western Ontario London, Ontario, ON, Canada. ${ }^{2}$ Department of Epidemiology, London School of Hygiene and Tropical Medicine, London, United Kingdom. ${ }^{3}$ Wellcome Trust Centre for Human Genetics, University of Oxford, Oxford, United Kingdom. ${ }^{4}$ Nuffield Department of Clinical Neurosciences, University of Oxford, Oxford, United Kingdom.

Received: 22 May 2012 Accepted: 20 May 2013

Published: 24 May 2013

\section{References}

1. Bernell O, Lapidus A, Hellers G: Risk factors for surgery and recurrence in 907 patients with primary ileocaecal Crohn's disease. Br J Surg 2000, 87:1697-1701.

2. Dasari BV, McKay D, Gardiner K: Laparoscopic versus Open surgery for small bowel Crohn's disease. Cochrane Database Syst Rev 2011 (1):CD006956 doi:10.1002/14651858.CD006956.pub2.

3. Rosman AS, Melis M, Fichera A: Metaanalysis of trials comparing laparoscopic and open surgery for Crohn's disease. Surg Endosc 2005, 19:1549-1555.

4. Tan JJY, Tjandra JJ: Laparoscopic surgery for Crohn's disease: A metaanalysis. Dis Colon Rectum 2007, 50:576-585.

5. Tilney HS, Constantinides VA, Heriot AG, Nicolaou M, Athanasiou T, Ziprin P, Darzi AW, Tekkis PP: Comparison of laparoscopic and open ileocecal resection for Crohn's disease: A metaanalysis. Surg Endosc 2006, 20:1036-1044.
6. Polle SW, Wind J, Ubbink DT, Hommes DW, Gouma DJ, Bemelman WA: Short-term outcomes after laparoscopic ileocolic resection for Crohn's disease: A Systematic review. Dig Surg 2006, 23:346-357.

7. Stroup DF, Berlin JA, Morton SC, Olkin I, Williamson GD, Rennie D, Moher D, Becker BJ, Sipe TA, Thacker SB: Meta-analysis of Observational Studies in Epidemiology: A Proposal for Reporting. JAMA 2000, 283:2008-2012.

8. The Newcastle-Ottawa Scale (NOS) for assessing the quality of nonrandomised studies in meta-analyses. http://www.ohri.ca/programs/ clinical_epidemiology/oxford.htm.

9. Higgins JPT, Green S: Cochrane Handbook for Systematic Reviews of Interventions. In Book Cochrane Handbook for Systematic Reviews of Interventions. City: The Cochrane Collaboration; 2011.

10. Alabaz O, Iroatulam AJN, Nessim A, Weiss EG, Nogueras JJ, Wexner SD: Comparison of laparoscopically assisted and conventional ileocolic resection for Crohn's disease. Eur J Surg 2000, 166:213-217.

11. Alessandroni L, Bertolini R, Campanelli A, Di Castro A, Natuzzi G, Saraco E, Scotti A, Tersigni R: Video-assisted versus open ileocolic resection in primary Crohn's disease: a comparative case-matched study. Updates Surg 2010, 62:35-40.

12. Bemelman WA, Slors JFM, Dunker MS, Van Hogezand RA, Van Deventer SJH, Ringers J, Griffioen G, Gouma DJ: Laparoscopic-assisted vs open ileocolic resection for Crohn's disease. A comparative study. Surg Endosc 2000, 14:721-725.

13. Benoist S, Panis Y, Beaufour A, Bouhnik Y, Matuchansky C, Valleur P: Laparoscopic ileocecal resection in Crohn's disease: A case-matched comparison with open resection. Surg Endosc 2003, 17:814-818.

14. Bergamaschi R, Pessaux P, Arnaud JP: Comparison of conventional and laparoscopic ileocolic resection for Crohn's disease. Dis Colon Rectum 2003, 46:1129-1133.

15. Brouquet $A$, Bretagnol F, Soprani A, Valleur $P$, Bouhnik $Y$, Panis $Y$ : A laparoscopic approach to iterative ileocolonic resection for the recurrence of Crohn's disease. Surgical Endoscopy and Other Interventional Techniques 2010, 24:879-887.

16. Courtney ED, Brennan M, Noble-Jamieson G, Heuschkel R, Davies RJ: Laparoscopic adult colorectal surgeon and adolescents with inflammatory bowel disease: A safe combination? Int J Colorectal Dis 2011, 26:357-360.

17. Da Luz MA, Stocchi L, Remzi FH, Geisler D, Hammel J, Fazio WW: Laparoscopic surgery for patients with crohn's colitis: A case-matched study. J Gastrointest Surg 2007, 11:1529-1533.

18. Diamond IR, Langer JC: Laparoscopic-assisted versus open ileocolic resection for adolescent Crohn disease. J Pediatr Gastroenterol Nutr 2001, 33:543-547.

19. Duepree HJ, Senagore AJ, Delaney CP, Brady KM, Fazio WW: Advantages of laparoscopic resection for ileocecal Crohn's disease. Dis Colon Rectum 2002, 45:605-610.

20. Dunker MS, Stiggelbout AM, van Hogezand RA, Ringers J, Griffioen G, Bemelman WA: Cosmesis and body image after laparoscopic-assisted and open ileocolic resection for Crohn's disease. Surg Endosc 1998, 12:1334-1340.

21. El-Gazzaz G, Geisler D, Hull T: Risk of clinical leak after laparoscopic versus open bowel anastomosis. Surgical Endoscopy and Other Interventional Techniques 2010, 24:1898-1903.

22. Eshuis EJ, Polle SW, Slors JF, Hommes DW, Sprangers MAG, Gouma DJ, Bemelman WA: Long-term surgical recurrence, morbidity, quality of life, and body image of laparoscopic-assisted vs. open ileocolic resection for Crohn's disease: A comparative study. Dis Colon Rectum 2008, 51:858-867.

23. Eshuis EJ, Slors JFM, Stokkers PCF, Sprangers MAG, Ubbink DT, Cuesta MA, Pierik EGJM, Bemelman WA: Long-term outcomes following laparoscopically assisted versus open ileocolic resection for Crohn's disease. Br J Surg 2010, 97:563-568.

24. Fichera A, Peng SL, Elisseou NM, Rubin MA, Hurst RD: Laparoscopy or conventional open surgery for patients with ileocolonic Crohn's disease? A prospective study. Surgery 2007, 142:566-571.

25. Huilgol RL, Wright CM, Solomon MJ: Laparoscopic versus Open lleocolic Resection for Crohn's Disease. J Laparoendosc Adv Surg Tech A 2004, 14:61-65.

26. Kishi D, Nezu R, Ito T, Taniguchi E, Momiyama T, Obunai S, Ohashi S, Matsuda H: Laparoscopic-assisted surgery for Crohn's disease: Reduced surgical stress following ileocolectomy. Surg Today 2000, 30:219-222.

27. Lauro A, Hamel C, Cirocchi R, Alonso-Poza A, Gervaz P, Doria C, Gruttadauria S, Giustozzi G, Wexner SD: Laparoscopic treatment for Crohn's disease. 
[Italian] Trattamento laparoscopico del morbo di Crohn. Minerva Chir 2004, 59:537-545.

28. Lowney JK, Dietz DW, Birnbaum EH, Kodner IJ, Mutch MG, Fleshman JW: Is there any difference in recurrence rates in laparoscopic ileocolic resection for Crohn's disease compared with conventional surgery? A long-term, follow-up study. Dis Colon Rectum 2006, 49:58-63.

29. Luan X, Gross E: Laparoscopic assisted surgery for Crohn's disease an initial experience and results. Journal of Tongji Medical University $=$ Tong $j i$ yi ke da xue xue bao 2000, 20:332-335.

30. Maartense S, Dunker MS, Slors JFM, Cuesta MA, Pierik EGJM, Gouma DJ, Hommes DW, Sprangers MA, Bemelman WA: Laparoscopic-assisted versus open ileocolic resection for Crohn's disease: A randomized trial. Ann Surg 2006, 243:143-149.

31. Milsom JW, Hammerhofer KA, Bohm B, Marcello P, Elson P, Fazio WW, Fleshman JW: Prospective, randomized trial comparing laparoscopic vs. conventional surgery for refractory ileocolic Crohn's disease. Dis Colon Rectum 2001, 44:1-9.

32. Msika S, lannelli A, Deroide G, Jouet P, Soule JC, Kianmanesh R, Perez N, Flamant $Y$, Fingerhut A, Hay JM: Can laparoscopy reduce hospital stay in the treatment of Crohn's disease? Dis Colon Rectum 2001, 44:1661-1666.

33. Nakajima K, Nezu R, Hirota M, Nishida T: The role of hand-assisted laparoscopic surgery in subtotal and total colectomy for Crohn's colitis. Surgical Endoscopy and Other Interventional Techniques 2010, 24:2713-2717.

34. Shore G, Gonzalez QH, Bondora A, Vickers SM: Laparoscopic vs conventional ileocolectomy for primary Crohn disease. Arch Surg 2003, 138:76-79.

35. Sica GS, laculli E, Benavoli D, Biancone L, Calabrese E, Onali S, Gaspari AL: Laparoscopic versus open ileo-colonic resection in crohn's disease: Short- and long-term results from a prospective longitudinal study. J Gastrointest Surg 2008, 12:1094-1102.

36. Stocchi L, Milsom JW, Fazio VW: Long-term outcomes of laparoscopic versus open ileocolic resection for Crohn's disease: Follow-up of a prospective randomized trial. Surgery 2008, 144:622-628.

37. Tabet J, Hong D, Kim CW, Wong J, Goodacre R, Anvari M: Laparoscopic versus open bowel resection for Crohn's disease. Can J Gastroenterol 2001, 15:237-242.

38. Tanaka S, Matsuo K, Sasaki T, Nakano M, Shimura H, Yamashita Y: Clinical outcomes and advantages of laparoscopic surgery for primary crohn's disease: Are they significant? Hepatogastroenterology 2009, 56:416-420.

39. Thaler K, Dinnewitzer A, Oberwalder M, Weiss EG, Nogueras JJ, Wexner SD: Assessment of long-term quality of life after laparoscopic and open surgery for Crohn's disease. Colorectal Dis 2005, 7:375-381.

40. Uchikoshi F, Ito T, Nezu R, Tanemura M, Kai Y, Mizushima T, Nakajima K, Tamagawa H, Matsuda C, Matsuda H: Advantages of laparoscope-assisted surgery for recurrent Crohn's disease. Surg Endosc 2004, 18:1675-1679.

41. Umanskiy K, Malhotra G, Chase A, Rubin MA, Hurst RD, Fichera A: Laparoscopic colectomy for crohn's colitis. A large prospective comparative study. J Gastrointest Surg 2010, 14:658-663.

42. Von Allmen D, Markowitz JE, York A, Mamula P, Shepanski M, Baldassano R: Laparoscopic-assisted bowel resection offers advantages over open surgery for treatment of segmental Crohn's disease in children. $J$ Pediatr Surg 2003, 38:963-965.

43. WU JS, Birnbaum EH, Kodner IJ, Fry RD, Read TE, Fleshman JW:

Laparoscopic-assisted ileocolic resections in patients with Crohn's disease: Are abscesses, phlegmons, or recurrent disease contraindications? Surgery 1997, 122:682-689.

doi:10.1186/1471-2482-13-14

Cite this article as: Patel et al:: Laparoscopic surgery for Crohn's Disease: a meta-analysis of perioperative complications and long term outcomes compared with open surgery. BMC Surgery 2013 13:14.

\section{Submit your next manuscript to BioMed Central and take full advantage of:}

- Convenient online submission

- Thorough peer review

- No space constraints or color figure charges

- Immediate publication on acceptance

- Inclusion in PubMed, CAS, Scopus and Google Scholar

- Research which is freely available for redistribution

Submit your manuscript at www.biomedcentral.com/submit
C Biomed Central 